\title{
PERKEMBANGAN PENGATURAN HALAL MENERUSI AKTA PERIHAL DAGANGAN 2011 DI MALAYSIA
}

\section{The Development of Regulations Concerning Halal through Trade Description Act 2011 in Malaysia}

\author{
Zalina Zakaria ${ }^{1}$ \\ Siti Zubaidah Ismail ${ }^{2}$
}

\begin{abstract}
The growing market and demand for halal products have created a question of whether the legal structure is adequate to cater for the development of halal industry. Eventhough the Malaysian government has prepared a healthy business infrastructure in order to enhance the positioning of the country as the main halal hub in the world, it does not mean that we are ahead of our counterparts in terms of regulations. The objective of this article is to examine the inadequacy of Trade Description Act 1972 to address the issue of halal and how the amendment made by Trade Description Act 2011 has strengthened many halal aspects. In collecting data, apart from reviewing the Act, interviews were conducted to complement the data. The article found that the amendment made by Trade Description Act 2011 has strengthened
\end{abstract}

\footnotetext{
Lecturer, Department of Shariah and Law, Academy of Islamic Studies, University of Malaya, Kuala Lumpur, zalina_jsu@um.edu.my

2 Senior Lecturer, Department of Shariah and Law, Academy of Islamic Studies, University of Malaya, Kuala Lumpur, szubaida@um.edu.my
} 
the aspects of enforcement, supervision and monitoring of halal logo as well as prosecution of related offences.

Keywords: regulations concerning halal, Trade Description Act, supervision, enforcement

\section{PENDAHULUAN}

Malaysia dikenali sebagai salah sebuah negara yang terkehadapan dalam pengaturan, penguatkuasaan dan pemantauan berkaitan halal. ${ }^{3}$ Logo halal yang dikeluarkan oleh Jabatan Kemajuan Islam Malaysia (JAKIM) selaku badan pensijilan halal Malaysia juga memiliki reputasi yang dikenali di peringkat antarabangsa. ${ }^{4}$ Ini adalah kerana semua aspek ini dikendalikan oleh agensi kerajaan dan berada dalam arus perdana perundangan negara. ${ }^{5}$ Namun, dari segi perundangan terdahulu, ketiadaan peruntukan khusus mengenai halal telah dikenalpasti sebagai halangan untuk menyemarakkan semua aspek yang disebutkan di atas. ${ }^{6}$ Biarpun Malaysia dilihat berpotensi menjadi sebuah negara hab halal, ini tidak bermakna negara tidak berhadapan dengan isu penyalahgunaan logo halal. Antara langkah yang diambil oleh kerajaan bagi memperkasakan perlindungan pengguna Muslim di Malaysia berkenaan halal adalah dengan memansuhkan Akta Perihal Dagangan $1972^{7}$ (selepas ini dirujuk sebagai APD 1972) dan menggantikannya dengan Akta Perihal Dagangan $2011^{8}$ (selepas ini dirujuk sebagai APD 2011) yang telah mendapat kelulusan Parlimen pada 11 Julai 2012. ${ }^{9}$ APD 2011 ini telah dikuatkuasakan

3 T.P., 'Destinasi Produk Halal Dunia,' Utusan Malaysia, 6 Mei 2008.

4 Nik Nazira Nik Yahya (Penolong Pengarah Kanan, Bahagian Pengurusan Strategik), dan Fakheezah Borhan (Penolong Pengarah Bahagian Standardisasi, Jabatan Standard Malaysia), dalam temu bual bersama beliau, pada 7 Oktober 2013.

5 YB Mejar General Dato' Seri Jamil Khir Haji Bahrom(B), dalam ucapan perasmian sempena Konvensyen Penguatkuasaan Halal Malaysia Peringkat Kebangsaan, 24 September 2013 di Hotel Grand Season Kuala Lumpur.

6 Haji Rabani Soyan (Ketua Penolong Pengarah Kanan Unit Perihal Dagangan, Bahagian Penguatkuasaan KPDNKK) dan Hamzah Mahadi (Ketua Penolong Pengarah Unit Perihal Dagangan, Bahagian Penguatkuasaan KPDNKK), dalam temu bual bersama beliau, pada 2 Oktober 2013.

$7 \quad$ Akta 87.

$8 \quad$ Akta 730.

9 Keratan Akhbar Utusan Malaysia pada 14 April 2012, 'Halal di bawah Akta Perihal Dagangan 2011,' dicapai dalam laman sesawang Jabatan Kemajuan Islam Malaysia, http://www.islam.gov.my/en/keratan-akhbar/halal-di-bawah-akta-perih al-dagangan-2011, pada 29 Mac 2014. 
pada 1 Januari 2012. ${ }^{10}$ Sebelum akta tersebut dikuatkuasakan, terdapat banyak laporan tentang pencabulan halal seperti penggunaan logo palsu serta penipuan penandaan halal. ${ }^{11}$ Sebagaimana yang telah disebutkan sebelum ini, permasalahan yang timbul antara lain adalah disebabkan oleh ketiadaan provisi yang khusus mengenai halal. ${ }^{12}$

\section{KEPENTINGAN PENGATURAN HALAL}

Isu-isu kepenggunaan berkenaan halal memerlukan suatu pengaturan undang-undang yang ketat dan teliti sama ada dari sudut pemantauan, penguatkuasaan serta kuasa dan bidang kuasa pihak-pihak tertentu. Secara umumnya, peruntukan undang-undang berkaitan halal tidak disentuh secara menyeluruh dan berada di bawah peruntukan yang berbeza-beza. ${ }^{13}$ Sebelum 2011, APD 1972 merupakan sebuah akta yang digubal untuk menyatu dan meminda undang-undang berhubung cap barang dagangan. Sejak APD 2011 diperkenalkan, peruntukan perundangan baharu menyatakan perihal barangbarang iaitu yang diadakan dalam perjalanan perdagangan dan petunjuk yang palsu atau yang mengelirukan tentang harga barang-barang. Selain itu, ianya bertujuan untuk memberi kuasa atau memberikan erti bagi apa-apa ungkapan atau petunjuk yang digunakan berhubung dengan harga barang-barang, caj atau kadar bagi perkhidmatan, tempat tinggal atau kemudahan, dan untuk mengawal selia, mengawal atau melarang penggunaan ungkapan atau petunjuk itu dalam perjalanan sesuatu perdagangan atau perniagaan. ${ }^{14}$ Pembaharuan akta

10 Pekeliling Pensijilan Halal Malaysia Bil. 1/2011, 1.

11 Sebagai contoh, kenyataan akhbar, T.P., 'Jalan Mudah' Harian Metro, 5 Januari 2011; T.P., 'Sijil Halal Tidak Sah: Peniaga Masih Berdegil,' Harian Metro, 10 April 2011; T.P., 'New Rules on Halal Cert.,'News Strait Times, 29 September 2011.

12 Haji Rabani Soyan (Ketua Penolong Pengarah Kanan Unit Perihal Dagangan, Bahagian Penguatkuasaan KPDNKK) dan Hamzah Mahadi (Ketua Penolong Pengarah Unit Perihal Dagangan, Bahagian Penguatkuasaan KPDNKK), dalam temu bual bersama beliau, pada 2 Oktober 2013.

13 Di bawah AKJS (WP) 1997 melalui Seksyen 42 iaitu Penyalahgunaan Tanda Halal. Lihat lebih lanjut dalam Zalina Zakaria, 'Keberkesanan Undang-Undang Makanan dan Produk Halal di Malaysia,' Jurnal Syariah 12/2 (2004): 100. Antaranya Akta Makanan 1983 (Seksyen 16 \& Seksyen 18), Akta Perlindungan Pengguna 1999 (Seksyen 8 \& Seksyen 10), Ordinan Binatang 1962 dan sebagainya. Rujuk Zalina Zakaria, 'Produk Halal' dalam Undang-Undang Islam di Malaysia: Prinsip dan Amalan, ed. Ahmad Hidayat Buang (Kuala Lumpur: Penerbit Universiti Malaya, 2007), 409-428.

14 Rujuk 'Muqaddimah’ APD 2011. 
tersebut turut memperlihatkan larangan untuk membuat pernyataan palsu atau mengelirukan tentang apa-apa perkhidmatan, tempat tinggal atau kemudahan yang diadakan dalam perjalanan perdagangan atau perniagaan serta memberi kuasa supaya maklumat atau arahan berhubung barang-barang dicapkan atau disertakan dengan barang-barang itu atau supaya dimasukkan ke dalam iklan; dan bagi maksud yang berkaitan.

Pada masa yang sama, akta ini juga adalah sebuah akta umum yang digunakan untuk menjaga kepentingan halal di Malaysia. Sebarang kesalahan melabelkan sesuatu barangan atau perkhidmatan sebagai halal sedangkan ia adalah sebaliknya dikira menyalahi akta ini kerana memperihalkan sesuatu barangan/perkhidmatan dengan tidak benar. Di bawah APD 1972 terdahulu, terdapat dua perintah yang khusus digubal berkenaan halal iaitu Perintah Perihal Dagangan (Penggunaan Perbahasaan Halal) 1975 dan Perintah Perihal Dagangan (Penandaan Makanan) 1975. Namun terdapat pelbagai isu yang menyebabkan APD 1972 dan perintah-perintah di bawahnya tidak dapat dikuatkuasakan. Bagi APD 2011 pula, terdapat juga dua perintah yang digubal di bawahnya iaitu Perintah Perihal Dagangan (Takrif Halal) 2011 dan juga Perintah Perihal Dagangan (Perakuan dan Penandaan Halal) 2011. Artikel ini akan membincangkan kelemahan yang ada dalam APD 1972 khususnya tentang penguatkuasaan halal. Perbincangan seterusnya akan dijelaskan tentang bagaimana APD 2011 mengatasi kekurangan APD 1972 dalam skop halal.

\section{PERUNDANGAN BERKAITAN HALAL SEBELUM APD 2011}

\section{Akta Perihal Dagangan 1972 (APD 1972)}

APD 1972 secara khususnya memberi perlindungan kepada para pengguna daripada segala bentuk amalan perdagangan yang tidak sihat. Hal ini termasuk sebarang perkara yang berkaitan dengan penandaan sesuatu barangan, yang berniat untuk menghalang para pengguna daripada mengetahui maklumat yang benar tentang sesuatu barangan termasuklah tanda harga. Begitu juga jika terdapat amalan yang menghalang pengguna dari mendapat maklumat tentang keaslian dan juga kualiti sesuatu barangan.

Terdapat peruntukan-peruntukan mengenai kesalahan beserta penalti dan juga kuasa bertindak berhubung kesalahan menggunakan perbahasan "Halal" kepada makanan yang tidak mematuhi hukum Syarak. Dalam hal ini, tugas penguatkuasaan akta ini adalah terletak di bawah autoriti Bahagian Penguatkuasa Kementerian Perdagangan Dalam Negeri, Koperasi dan 
Kepenggunaan (KPDNKK). Ini adalah kerana logo halal merupakan salah satu daripada perihal dagangan terhadap produk makanan, minuman, premis atau pun rumah sembelihan yang menggunakan logo halal. Akta ini juga memberi kuasa kepada Menteri untuk menghendaki maklumat-maklumat yang perlu sebelum sesuatu barang dibekalkan atau ditawar untuk dibekalkan dalam perjalanan perdagangan atau perniagaan.

Seksyen 18 (1) Akta ini membabitkan penalti kepada kesalahan yang dilakukan oleh individu, yang jika disabit kesalahan pada kali pertama boleh didenda sehingga RM100,000 atau dipenjarakan tidak melebihi 3 tahun atau kedua-duanya. Bagi kesalahan kedua dan seterusnya, denda boleh dikenakan jika sabit kesalahan sehingga RM200,000 dan penjara tidak melebihi 6 tahun atau kedua-duanya.

Seksyen 18 (2) memperuntukkan penalti untuk syarikat atau pertubuhan perbadanan yang terlibat yang boleh dikenakan denda sehingga RM250,000 kali pertama disabit kesalahan dan tidak melebihi RM500,000 bagi kesalahan kedua dan seterusnya.

Seksyen 29 (1) dan (2) Akta ini mensabitkan kesalahan bagi sesiapa yang menghalang pegawai dari menjalankan tugasnya dan kesalahan bagi apa-apa maklumat atau memberikan pernyataan yang diketahui palsu. Penalti untuk kesalahan ini adalah denda tidak melebihi RM2,000 atau penjara tidak lebih dari satu tahun atau kedua-duanya.

\section{Perintah Perihal Dagangan (Penggunaan Perbahasaan "Halal") 1975}

Perintah Perihal Dagangan (Penggunaan Perbahasaan "Halal”) 1975 adalah merupakan perintah yang dibuat oleh Menteri melalui peruntukan Seksyen 10 APD 1972. Perintah ini bertujuan memberikan takrif berhubung dengan perbahasaan berkaitan halal. Menurut Perintah ini, perkataan 'Halal', 'Makanan Orang Islam' atau 'Ditanggung Halal' atau mana-mana perbahasaan yang membawa maksud sedemikian sebagaimana yang dikehendaki hukum Syarak telah diberikan takrif yang agak jelas. Hukum Syarak di sini juga turut ditakrifkan oleh Perintah di atas sebagai "empat mazhab utama dipersetujui oleh Yang DiPertuan Agong dan Raja-Raja Malaysia iaitu mazhab Syafie, Hanafi, Hanbali dan Maliki."

Menurut Manual Pensijilan Halal Malaysia JAKIM 2005, 'Halal', 'Ditanggung Halal', 'Makanan Islam' dan lain-lain perbahasaan yang digunakan ke atas makanan dalam apa-apa jua bentuk sekalipun hendaklah bermaksud seperti yang tertakrif di dalam Perintah di atas adalah seperti berikut: 
"bukanlah dan juga tidaklah daripada mengandungi apa-apa bahagian daripada binatang orang Islam yang dilarang oleh hukum Syarak memakannya atau tidak disembelih mengikut hukum Syarak, tidaklah mengandungi apa-apa benda yang difikirkan sebagai najis mengikut hukum Syarak, tidak disedia, diproses, atau dikilang dengan menggunakan apa-apa alat yang tidak bebas dari apa-apa najis mengikut hukum Syarak, tidaklah dalam masa menyediakan, memproses atau menyimpan itu bersentuhan atau berdekatan dengan apa-apa makanan yang tidak memenuhi perenggan $a, b$, atau c atau apa-apa benda yang difikirkan sebagai najis mengikut hukum Syarak."

Najis mengikut hukum Syarak ialah jika benda itu sendiri najis dan tidak boleh disucikan seperti daging babi, darah dan bangkai, benda suci yang terkena najis dan ia tidak boleh disucikan dan juga benda suci yang terkena najis dan ia boleh disucikan. Sedikit sebanyak melalui takrifan yang dibuat, apa yang dapat dilihat adalah mengikut hukum Syarak selain dari binatang yang sudah jelas diharamkan adalah ditegah untuk memakannya.

Selain dari itu, Perintah ini menegaskan binatang-binatang dari jenis yang dibenarkan orang Islam memakannya juga belum boleh dianggap halal sekiranya ia tidak melalui proses penyembelihan sebagaimana yang ditetapkan oleh hukum Syarak. Alat-alatan yang digunakan juga hendaklah bersih dari sebarang najis termasuklah juga proses penghasilannya adalah perlu diberi perhatian.

Melalui peruntukan tersebut, perbahasaan berkenaan halal bukanlah sesuatu yang boleh digunakan sewenang-wenangnya kerana apabila ia digunakan ke atas makanan, maka ia hendaklah terlebih dahulu mematuhi kriteria yang ditetapkan oleh hukum Syarak.

\section{Perintah Perihal Dagangan (Penandaan Makanan) 1975}

Perintah ini dibuat di bawah kuasa yang diperuntukkan di bawah Seksyen 11 Akta Perihal Dagangan 1972. Secara amnya, Perintah ini menyebut di bawah Perintah 2 (1) bahawa makanan yang telah dispesifikasikan di bawah Perintah Perihal Dagangan (Perbahasaan Halal) 1975 adalah tidak boleh dikeluarkan melainkan mestilah dilabelkan, atau ditandakan menggunakan apa-apa tanda yang menyatakan makanan tersebut adalah halal. Di bawah Perintah 2 (2) pula dinyatakan sebagaimana berikut:

"Semua daging dan perkakas dalam yang mentah termasuk daging yang perkakas-perkakas dalam ayam-itik tidak 


\begin{abstract}
dibenarkan dilabelkan melainkan ianya ditanda dengan label, tag atau lain-lain tanda yang menunjukkan bahawa daging atau perkakas-perkakas dalam itu telah atau tidak pernah didingin atau dibekukan."
\end{abstract}

Tujuan perlabelan sedemikian adalah untuk melindungi pengguna supaya tidak mudah tertipu dengan sebarang kekeliruan yang disebabkan oleh pengeluar/penjual ingin mengaut keuntungan yang berlebihan terhadap makanan yang dibekalkan.

\title{
Masalah dan Kesukaran Pemantauan Serta Penguatkuasaan Halal di Bawah Perundangan APD 1972 dan Perintah-Perintah yang Terkandung di Bawahnya
}

Sungguhpun APD 1972 dan perintah-perintah di bawahnya telah diwujudkan, namun akta dan perintah-perintah ini sukar dilaksanakan dalam usaha menguatkuasakan kesalahan berkaitan halal. Masalah utama adalah disebabkan ketiadaan peruntukan khusus yang memberikan bidang kuasa kepada pihakpihak tertentu yang mengendalikan halal. Hal ini disebabkan oleh bidang kuasa yang mengawal selia akta ini adalah berada di bawah KPDNKK (dahulunya dikenali sebagai Kementerian Perdagangan dalam Negeri dan Hal Ehwal Pengguna (KPDNHEP). Kementerian ini telah diberikan kuasa untuk mengawal selia APD 1972 dan perundangan subsidiari di bawahnya termasuk aspek perundangan berkaitan halal di Malaysia yang dibuat berdasarkan peruntukan APD 1972, sedangkan pengendalian halal telah diserahkan kepada Jabatan Kemajuan Islam Malaysia (JAKIM) melalui Bahagian Hab Halal yang bertanggungjawab untuk mengawal selia pensijilan, pengauditan permohonan dan pembaharuan sijil halal. ${ }^{15}$ Sungguhpun begitu, ia tidak dibuat melalui mana-mana peruntukan perundangan.

Melalui mandat yang telah diserahkan kepada JAKIM, JAKIM (termasuk juga Jabatan Agama Islam Negeri (JAIN) yang menjalankan pemeriksaan

15 Penyerahan tanggungjawab ini adalah sebenarnya peralihan pentadbiran semula pensijilan halal yang telah diambil alih oleh Perbadanan Pembangunan Industri Halal (HDC) semenjak 17 April 2008 kepada JAKIM. Ia adalah berdasarkan keputusan Jemaah Menteri yang telah bersetuju pada 8 Julai 2009 bahawa JAKIM telah diberikan tanggungjawab semula dan berkuatkuasa serta merta untuk mengeluarkan pensijilan halal Malaysia bagi produk dalam dan luar negara dengan menggunakan logo halal JAKIM. Rujuk http:/www.islam.gov.my/en/ majlis-penyerahan-semula-pengurusan-pensijilan-halal-daripada-hdc-ke-jakim; Hajah Hakimah Mohd Yusoff (Pengarah Bahagian Hab Halal JAKIM), dalam temu bual bersama beliau, pada 6 September 2013. 
di peringkat negeri) adalah agensi utama yang bertanggungjawab dalam mengeluarkan Sijil Pengesahan dan Logo Halal kepada pemohon-pemohon yang telah memenuhi garis panduan yang ditetapkan. Walaupun JAKIM diberikan autoriti penuh mengendalikan permohonan dan mengeluarkan sijil serta logo halal, namun dari segi pelaksanaan penguatkuasaan dan pendakwaan terhadap sebarang kesalahan penyalahgunaan logo halal adalah terletak di bawah bidang kuasa KPDNHEP. JAKIM pada masa tersebut hanya boleh bertindak dari sudut pentadbiran sahaja. ${ }^{16}$ Akibat daripada itu, apabila penguatkuasaan dijalankan, pihak JAKIM hanya boleh membuat tindakan apabila pihak KPDNHEP ada bersama mereka pada masa serbuan atau penguatkuasaan dijalankan. Dalam erti kata lain, penguatkuasa sebenar jika dirujuk kepada akta ini adalah pihak KPDNHEP. Begitu juga dalam setiap tindakan seperti pemeriksaan mengejut terhadap premis adalah bergantung sepenuhnya kepada pihak penguatkuasa KPDNHEP sedangkan JAKIM merupakan agensi yang menjalankan keseluruhan prosedur.

Daripada perspektif aduan pengguna pula, sama ada tentang penyalahgunaan sijil atau logo halal, pihak JAKIM perlu memaklumkan kepada Bahagian Penguatkuasaan KPDNHEP terlebih dahulu sebelum serbuan dijalankan di tempat terbabit. ${ }^{17}$ Tugas JAKIM di sini adalah untuk memastikan sama ada syarikat atau pengeluar yang diadukan itu benarbenar mempunyai Sijil Pengesahan Halal atau Logo Halal yang diluluskan dan sama ada pihak tersebut menepati garis panduan yang ditetapkan atau sebaliknya. Jika JAKIM menjalankan serbuan tanpa memaklumkan kepada pihak KPDNHEP dan didapati bahawa pihak yang diserbu telah melakukan kesalahan-kesalahan tersebut, bidangkuasa JAKIM hanyalah terhad kepada menggantung atau menarik balik sijil atau logo yang dikeluarkan dan tidak mempunyai bidangkuasa untuk menjalankan sebarang pendakwaan atau penguatkuasaan. Dari sudut pendakwaan, kerjasama JAKIM diperlukan di Mahkamah oleh pihak KPDNHEP untuk memberi keterangan atau bertindak sebagai saksi. ${ }^{18}$

16 Lihat Lokman Abd Rahman, Produk Halal: Kepenggunaan, Teknologi dan Prosedur (Melaka: Jabatan Agama Islam Melaka dan Majlis Agama Islam Melaka, 2002).

17 Aduan juga boleh dibuat kepada Bahagian Penguatkuasaan, JAIN supaya disiasat di bawah Seksyen 42 AKJS 1997 kerana menyalahgunakan tanda halal. Namun, undang-undang ini hanya terhad kepada mereka yang beragama Islam sahaja.

18 Terdapat satu lagi undang-undang iaitu Akta Kesalahan Jenayah Syariah (Wilayah Persekutuan) 1997 yang memperuntukkan kesalahan penyalahgunaan tanda halal. Seksyen 42 memperuntukkan, mana-mana orang yang mempamerkan pada atau berkenaan dengan mana-mana makanan atau minuman yang tidak halal, apa- 
Terdapat juga masalah-masalah disebabkan isu bidang kuasa. Seperti yang telah dinyatakan, hukuman bagi penyalahgunaan logo dan seumpamanya adalah di bawah Seksyen 18(1), Akta Perihal Dagangan 1972 yang mana bagi kesalahan ini denda yang dikenakan adalah sebanyak RM100,000 jika membabitkan individu bagi kesalahan kali pertama, juga boleh dikenakan penjara selama tidak lebih tiga tahun manakala denda sebanyak RM250,000 jika dilakukan oleh sesebuah pertubuhan mengikut Seksyen 18(2). Seksyen 29 (1) dan 29 (2) adalah suatu penalti yang dikhususkan bagi apa-apa pemberian maklumat palsu yang dibuat dan boleh dikenakan denda tidak melebihi RM2,000 atau penjara tidak lebih dari setahun atau kedua-duanya. Walau bagaimanapun, rata-rata hukuman tersebut hanyalah di atas kertas, kerana dari segi realitinya tindakan yang biasanya dikenakan kepada mereka yang didapati bersalah ialah membayar kompaun sahaja (berasakan Seksyen 18 Akta) dan jumlah kompaun yang paling tinggi hanyalah separuh dari amaun sebenar. ${ }^{19}$ Bagi pengusaha atau pengeluar yang mendapat untung berlipat kali ganda, nilai tersebut adalah terlalu kecil dan amaun tersebut dilihat masih tidak mampu menjadi deterrent kepada pesalah. ${ }^{20}$

\section{PEMBAHARUAN BAGI MEMBANTERAS PENCABULAN HALAL}

Disebabkan timbulnya beberapa perkara yang telah dikenal pasti menggugat kelancaran dalam pengaturan halal, APD 2011 diperkenalkan bagi menggantikan APD 1972 dan telah melibatkan pindaan yang besar serta merangkumi pelbagai perkara. Antara perubahan yang signifikan melalui penggubalan APD 2011 adalah dengan menambahbaik perundangan berkenaan halal, selain ada juga peruntukan berkaitan harta intelek, iklan, penalti kesalahan dan aspek penguatkuasaan berbanding APD 1972.

apa tanda yang menunjukkan bahawa makanan atau minuman itu adalah halal adalah melakukan suatu kesalahan dan apabila disabitkan boleh didenda tidak melebihi lima ribu ringgit atau dipenjarakan selama tempoh tidak melebihi tiga tahun atau kedua-duanya. Namun, kesalahan ini terletak di bawah bidang kuasa Jabatan Agama Islam Wilayah Persekutuan di mana aduan perlu dibuat di Bahagian Penguatkuasaan yang akan menyiasat dan jika ada kes, pendakwaan akan dilakukan oleh Bahagian Pendakwaan di Mahkamah Syariah.

19 Haji Rabani Soyan (Ketua Penolong Pengarah Kanan Unit Perihal Dagangan, Bahagian Penguatkuasaan KPDNKK) dan Hamzah Mahadi (Ketua Penolong Pengarah Unit Perihal Dagangan, Bahagian Penguatkuasaan KPDNKK), dalam temu bual bersama beliau, pada 2 Oktober 2013.

20 Zalina Zakaria, Keberkesanan Undang-Undang Makanan dan Produk Halal di Malaysia,' 102. 


\section{Akta Perihal Dagangan 2011}

Sebagaimana yang telah dijelaskan, APD 2011 telah digubal bagi menggantikan APD 1972 yang telah dimansuhkan. Tujuan APD 2011 diwujudkan ialah untuk menggalakkan amalan perdagangan yang baik dengan melarang perihal dagangan palsu dan pernyataan, pengendalian dan amalan. Hal ini adalah berpunca dari kebimbangan terhadap pengeksploitasian pengguna dengan logo halal oleh pengeluar. ${ }^{21}$ Maka salah satu daripada aspek yang ditekankan dan ditambah ialah berkenaan isu halal. Penggubalan APD 2011 ini adalah bertujuan untuk mengawal selia hal ehwal dan pengaturan halal di Malaysia. Antara yang paling penting adalah suatu peruntukan khusus memberikan kuasa kepada badan khusus sahaja untuk mengeluarkan pensijilan halal dan melarang sijil dan logo halal oleh mana-mana syarikat swasta. Selain itu, kenyataan yang menunjukkan halal secara self declaration juga adalah tidak dibenarkan. ${ }^{22}$ Sebelum ini, perundangan khusus yang menyebut halal hanya terkandung di bawah Perintah Perihal Dagangan (Penggunaan Perbahasaan "Halal") 1975 sahaja. ${ }^{23}$ Dengan wujudnya APD 2011 dan seterusnya pengkanunan Perintah Perihal Dagangan 2011 (selepas ini dirujuk sebagai PPD 2011), maka Perintah Perihal Dagangan (Penggunaan Perbahasaan "Halal") 1975 telah dibatalkan.

Penggubalan akta ini merupakan sebahagian daripada usaha serius kerajaan bagi mengukuhkan perundangan berkaitan halal. Ketiadaan undang-undang halal yang spesifik sejak dahulu telah dikenal pasti dan ini mendorong pindaan dibuat dan memasukkan Bahagian 6 berkenaan kuasa untuk mentakrifkan istilah, menghendaki supaya maklumat diberikan, dan sebagainya. Terdapat 2 seksyen utama berkenaan perkara ini iaitu Seksyen 28 berkenaan dengan Perintah Takrif dan Seksyen 29 bekaitan dengan Perintah Cap Bermaklumat dan Perakuan. Selain itu, berdasarkan kuasa di bawah Seksyen 69(2)(c) APD 2011 iaitu berkenaan dengan kuasa Menteri untuk membuat peraturanperaturan bagi menetapkan fi yang akan dikenakan dengan penggunaan apa-

21 Zalina Zakaria, 'Keberkesanan Undang-Undang Makanan dan Produk Halal di Malaysia,' 100.

22 Bernama, 'Halal Logo Issued by JAKIM Will Be Accepted From Next Year,' dalam http://www.hdcglobal.com/upload-web/cms-editor-files/HDC-122file/28Sep 2011\%28Bernama_com\%29-OnlyHalalLogoIssuedbyJakimWillbeAcceptedfr omNextYear.jpg, diakses pada 27 Mac 2014. Sebelum penggubalan APD 2011 tersebut bagi permohonan Sijil Halal boleh dibuat kepada pihak JAKIM, Majlis Agama Islam Negeri (MAIN) atau syarikat-syarikat swasta. Fenomena ini mengakibatkan wujudnya perbezaan bentuk Sijil Halal dari setiap negeri dan Sijil Halal yang dikeluarkan oleh pihak-pihak swasta tersebut.

23 Lihat Seksyen 2 dan 3 Perintah Perihal Dagangan 1975. 
apa ungkapan atau petunjuk yang digunakan dalam perniagaan, maka Peraturan Perihal Dagangan (Fi Perakuan dan Penandaan) 2011 telah diwujudkan.

APD 2011 mengandungi peruntukan khusus sebagaimana ditunjukkan dalam Jadual 1 di bawah.

Jadual 1: Ringkasan APD 2011 dan PPD 2011.

\begin{tabular}{|c|c|c|}
\hline Punca Kuasa & Perintah Baru & Huraian Perundangan \\
\hline $\begin{array}{c}\text { Seksyen } 28 \\
\text { APD } 2011\end{array}$ & $\begin{array}{c}\text { PPD (Takrif Halal) } \\
2011\end{array}$ & $\begin{array}{l}\text { - Takrif halal } \\
\text { - Kesalahan } \\
\text { - Penalti }\end{array}$ \\
\hline $\begin{array}{l}\text { Seksyen } 29 \\
\text { APD } 2011\end{array}$ & $\begin{array}{l}\text { PPD (Penandaan } \\
\text { Halal) } 2011\end{array}$ & $\begin{array}{l}\text { - Pihak berkuasa berwibawa } \\
\text { - Perakuan perihal halal } \\
\text { - Perakuan perihal halal bagi } \\
\text { makanan atau barangan import } \\
\text { - Penandaan ke atas makanan } \\
\text { - Permohonan perakuan dan fi } \\
\text { kesalahan }\end{array}$ \\
\hline $\begin{array}{l}\text { Seksyen 69(2) } \\
\text { (c) APD } 2011\end{array}$ & PPD (Fi) 2011 & - Permohonan dan peraturan fi \\
\hline
\end{tabular}

Sumber: Analisis Penyelidik.

Sebagaimana yang dijelaskan di atas, mulai tahun 2011, APD 2011 telah dikuatkuasakan dengan memasukkan Bahagian 6 iaitu tentang Kuasa Untuk Mentakrifkan Istilah, Menghendaki Supaya Maklumat Diberikan dan sebagainya. Bahagian 6 ini mengandungi dua seksyen yang menggariskan perihal berkaitan Perintah Takrif dan juga Perintah Cap Bermaklumat dan Perakuan. Kewujudan Seksyen 28 dalam APD 2011 dilihat sebagai penambahbaikan dalam APD 2011 dalam konteks menguatkuasakan segala perkara berkaitan halal di negara ini berbanding APD 1972 sebelum ini.

\section{Seksyen 28 (1) APD 2011}

Seksyen 28 (1) APD 2011 menyatakan:

(1) "Jika ternyata pada Menteri:-

(a) bahawa adalah demi kepentingan orang yang kepadanya apa-apa barang-barang dibekalkan atau apa-apa perkhidmatan diadakan; atau 
(b) bahawa adalah demi kepentingan orang yang kepadanya apa-apa barang-barang dieksport dan tidak berlawanan dengan kepentingan orang yang kepadanya barang-barang itu dibekalkan di Malaysia.

bahawa apa-apa ungkapan yang digunakan berhubungan dengan barang-barang atau perkhidmatan itu patut difahami sebagai mempunyai pengertian yang tertentu, Menteri boleh melalui perintah, memberikan apa-apa pengertian sama ada-

kepada ungkapan itu apabila digunakan dalam perjalanan perdagangan atau perniagaan sebagai, atau sebagai sebahagian daripada, suatu perihal dagangan yang digunakan bagi barangbarang atau perkhidmatan itu; atau

kepada ungkapan itu apabila digunakan sedemikian dalam apa-apa hal keadaan yang dinyatakan dalam perintah itu, dan jika suatu pengertian itu diberikan sedemikian kepada suatu ungkapan ia hendaklah disifatkan bagi maksud akta ini sebagai mempunyai pengertian itu apabila digunakan sebagaimana yang disebut dalam perenggan (A) atau, mengikut mana-mana yang berkenaan, perenggan (B)

(2) "Menjadi suatu kesalahan bagi mana-mana orang yang menggunakan ungkapan yang telah ditakrifkan dalam perintah yang dinyatakan dalam subseksyen (1) sebagai perihal dagangan bagi barang-barang atau perkhidmatan, dengan tujuan untuk memperdaya atau mengelirukan orang yang mahu membeli atau mendapatkan barang-barang atau perkhidmatan itu, seolah-olah barang-barang atau perkhidmatan itu dibekalkan menurut takrif yang diberikan kepada ungkapan itu."

(3) "Mana-mana orang yang melakukan suatu kesalahan di bawah seksyen ini boleh, apabila disabitkan-

(a) jika orang itu ialah suatu pertubuhan perbadanan didenda tidak melebihi lima juta ringgit, dan bagi kesalahan yang kedua atau yang berikutnya, didenda tidak melebihi sepuluh juta ringgit; atau

(b) jika orang itu bukan suatu pertubuhan perbadanan, didenda tidak melebihi satu juta ringgit atau dipenjarakan selama tempoh tidak melebihi tiga tahun atau kedua-duanya, dan bagi kesalahan yang kedua atau yang berikutnya, didenda tidak melebihi lima 
juta ringgit atau dipenjarakan selama tempoh tidak melebihi lima tahun atau kedua-duanya."

Peruntukan seksyen ini bertujuan, antara lain, adalah untuk melarang dan seterusnya mengambil tindakan terhadap mana-mana orang yang memperdayakan orang ramai bahawa produk yang ditawarkan adalah produk yang halal untuk digunakan. Melalui penguatkuasaan Seksyen 28 ini, ia dapat mengelakkan pengguna daripada terperdaya atau dikelirukan oleh ungkapan tertentu yang jelas bercanggah dengan barangan dan perkhidmatan yang ditawarkan khususnya yang berkaitan dengan barangan dan perkhidmatan halal. Dalam erti kata lain, adalah merupakan satu kesalahan melabel atau memperihal sesuatu itu sama ada makanan atau barang-barang gunaan lain untuk menunjukkan ia boleh dimakan/digunakan oleh orang Islam. Berasaskan seksyen ini, Menteri yang yang mengawal selia akta iaitu Menteri Perdagangan Dalam Negeri, Koperasi dan Kepenggunaan telah mengeluarkan satu perintah.

Sebagaimana yang ditunjukkan dalam Jadual 1, Seksyen 28 ini juga menjadi punca kuasa bagi perintah berikut:

\section{Perintah Perihal Dagangan (Takrif Halal) $2011^{24}$}

Menurut Perintah Perihal Dagangan (Takrif Halal) 2011 (selepas ini PPD (Takrif Halal) 2011), sesuatu makanan, barang atau perkhidmatan yang dikatakan halal merupakan indikasi bahawa sesuatu makanan atau barangan atau perkhidmatan itu boleh dimakan atau digunakan oleh orang Islam. Justeru, perenggan 3(1) PPD (Takrif Halal) 2011 menetapkan bahawa apabila suatu makanan atau barang-barang diperihalkan sebagai halal atau diperihalkan dengan apa-apa ungkapan lain untuk menunjukkan makanan atau barangbarang itu boleh dimakan atau digunakan oleh orang Islam, maka ungkapan itu memberi erti bahawa makanan atau barang itu:

"Bukanlah dan tidaklah terdiri daripada atau mengandungi apaapa bahagian atau benda daripada binatang yang dilarang oleh hukum Syarak bagi orang Islam untuk memakannya atau yang tidak disembelih mengikut hukum Syarak;

i. Tidak mengandungi apa-apa benda yang najis mengikut hukum Syarak;

ii. Tidak memabukkan mengikut hukum Syarak;

24 Sebagaimana Perintah Perihal Dagangan (Takrif Halal) (Pindaan) 2012 yang berkuat kuasa pada 1 Mac 2012. 


\section{iii. Tidak mengandungi mana-mana bahagian anggota manusia atau hasilan daripadanya yang tidak dibenarkan oleh hukum Syarak; \\ iv. Tidak beracun atau memudaratkan kesihatan; \\ v. Tidak disediakan, diproses atau dikilang menggunakan apa- apa peralatan yang dicemari najis mengikut hukum Syarak; dan}

vi. Tidaklah dalam masa menyediakan, memproses atau menyimpannya bersentuhan, bercampur atau berdekatan dengan apa-apa makanan yang gagal memenuhi perenggan (a) dan (b)."

Perenggan 3(2) PPD (Takrif Halal) 2011 menyatakan bahawa apabila perkhidmatan yang berhubung dengan makanan atau barang-barang diperihalkan sebagai halal atau diperihalkan dengan apa-apa ungkapan lain untuk menunjukkan perkhidmatan itu boleh digunakan oleh orang Islam, ungkapan tersebut bererti perkhidmatan yang berhubung dengan makanan atau barang-barang yang dijalankan mengikut hukum Syarak. Tafsiran "hukum Syarak" dalam Perintah Perihal Dagangan (TakrifHalal)2011 di bawah Seksyen 28 APD 2011 ini bermaksud dari segi undang-undang Islam dalam mazhab Syafie, atau undang-undang Islam dalam mana-mana satu daripada mazhab lain sama ada Hanafi, Maliki dan Hanbali yang telah dipersetujui oleh Yang DiPertuan Agong untuk dikuatkuasakan di Wilayah Persekutuan Kuala Lumpur, Labuan dan Putrajaya, Pulau Pinang, Melaka, Sabah dan Sarawak atau oleh Raja bagi mana-mana negeri untuk dikuatkuasakan di negeri masing-masing. ${ }^{25}$ Bagi tafsiran "makanan" pula, ia termasuklah setiap barang yang dikilangkan, dijual atau digambarkan untuk digunakan sebagai makanan dan minuman bagi kegunaan manusia atau yang memasuki ke dalam atau digunakan dalam komposisi, penyediaan, pengawetan, mana-mana makanan atau minuman bagi kegunaan manusia dan termasuklah konfeksi, bahan kunyahan dan apa-apa bahan bagi makanan, minuman, konfeksi atau bahan kunyahan itu. ${ }^{26}$ Manakala istilah "perkhidmatan" pula ditakrifkan sebagai perkhidmatan yang berkaitan dengan makanan atau barang-barang termasuklah pengangkutan, penyimpanan dan pemprosesan bahan mentah, penyajian dan peruncitan makanan atau barang-barang tersebut. ${ }^{27}$

\footnotetext{
25 Fasal 2, Perintah Perihal Dagangan (Takrif Halal).

26 Fasal 2, Perintah Perihal Dagangan.

27 Fasal 2, Perintah Perihal Dagangan.
} 
Seperti dinyatakan dalam perenggan 3(3) PPD (Takrif Halal) 2011 bahawa mana-mana orang yang membekalkan atau menawarkan untuk membekalkan apa-apa makanan, barang-barang atau perkhidmatan yang berhubung dengan makanan atau barang-barang itu yang diperihalkan sebagai halal atau diperihalkan dengan apa-apa ungkapan lain yang bertentangan dengan perenggan ini adalah melakukan suatu kesalahan.

a) Kesalahan Bagi Memperdayakan atau Mengelirukan

Bagi mengekang perbuatan yang dianggap salah sebagaimana yang dijelaskan di bawah perenggan 3(3) di atas, maka suatu kesalahan iaitu kesalahan memperdayakan atau mengelirukan telah diwujudkan di bawah PPD (Takrif Halal) 2011. Seksyen 4(1) menetapkan:

"Mana-mana orang yang membekalkan atau menawarkan untuk membekalkan apa-apa makanan dengan membuat apa-apa representasi atau perbuatan yang boleh memperdayakan atau mengelirukan mana-mana orang bahawa makanan itu adalah halal dan boleh dimakan oleh orang Islam adalah melakukan suatu kesalahan."

Perbuatan mengelirukan orang ramai tentang status sesuatu makanan atau barang ialah, antara lain, membuat suatu representasi salah termasuklah penggunaan ayat-ayat suci al-Quran yang berleluasa jika tidak dikawal di premis di mana makanan itu dijual, dipamerkan atau dibekalkan. Ini ditegaskan oleh Seksyen 4(2) sepertimana berikut:

"Bagi maksud subperenggan (1), "representasi atau perbuatan" termasuklah penggunaan ayat-ayat suci al-Quran atau apa-apa perkara atau objek yang berhubung dengan agama Islam sama ada di premis di mana makanan itu dijual atau dibekas di mana makanan itu dibekalkan."

b) Penalti

Bagi kesalahan di bawah PPD ini, penalti yang boleh dikenakan adalah sepertimana yang diperuntukkan di bawah Seksyen 5 yang berbunyi:

"Mana-mana orang yang melakukan kesalahan di bawah Perintah ini boleh, apabila disabitkan:

Jika orang itu ialah suatu pertubuhan perbadanan, didenda tidak melebihi lima juta ringgit, dan bagi kesalahan yang kedua atau 
yang berikutnya, didenda tidak melebihi sepuluh juta ringgit; atau

Jika orang itu bukan suatu pertubuhan perbadanan, didenda tidak melebihi satu juta ringgit atau dipenjarakan selama tempoh tidak melebihi tiga tahun atau kedua-duanya, dan bagi kesalahan yang kedua atau yang berikutnya, didenda tidak melebihi lima juta ringgit atau dipenjarakan selama tempoh tidak melebihi lima tahun atau kedua-duanya."

Penalti yang dikenakan di bawah Perintah ini merupakan penalti yang tertinggi. Melalui peruntukan Seksyen 28 tersebut memperuntukkan iaitu Menteri berkuasa untuk menetapkan kesalahan bagi mana-mana orang yang memperdayakan atau mengelirukan orang awam bahawa barangan yang ditawarkan menepati takrifan yang dibuat oleh Menteri di bawah seksyen ini. Ia bertujuan antara lain bagi mengambil tindakan terhadap mana-mana orang yang memperdayakan orang ramai bahawa makanan yang ditawarkan adalah halal. ${ }^{28}$

Dari sudut pengaturan halal, melalui peruntukan seksyen ini, tindakan boleh diambil terhadap mana-mana orang yang memperdayakan orang ramai bahawa produk yang yang ditawarkan adalah halal untuk digunakan. Melalui penguatkuasaan seksyen ini, ia akan dapat mengelakkan pengguna daripada dikelirukan atau diperdayakan oleh ungkapan tertentu yang jelas bercanggah dengan barangan dan perkhidmatan yang ditawarkan khususnya yang berkaitan dengan barangan dan perkhidmatan halal. Selain itu, provisi ini juga menghalang perbuatan 'self declaration'. 'Self declaration' di sini bermaksud apa-apa sahaja ungkapan, perkataan yang digunakan, termasuk juga melalui representasi atau perbuatan yang boleh dikaitkan oleh masyarakat sebagai halal adalah tidak dibenarkan lagi. Antara contoh ungkapan yang selalu digunakan sebelum ini adalah seperti 'ditanggung halal', 'makanan orang Islam', 'terjamin halal', 'halalan thoyyiban', dan lain-lain. Begitu juga sebarang perbuatan dan representasi yang boleh menunjukkan pengguna bahawa ia boleh dikaitkan dengan agama Islam sebagai contoh penggunaan ayat-ayat suci al-Quran yang dibingkaikan di hadapan kedai/restoran, atau apa-apa sahaja perkara atau objek yang berhubung dengan agama Islam sama ada di premis di mana makanan itu dijual atau di bekas di mana makanan itu dibekalkan.

28 Seksyen 28, Akta Perihal Dagangan 2011. 


\section{Seksyen 29 APD 2011}

Seksyen 29 APD 2011 menyatakan:

(1) "Jika ternyata pada Menteri adalah perlu atau suai manfaat demi kepentingan orang yang kepadanya apa-apa barang atau apa-apa perkhidmatan yang berhubungan dengan barang-barang itu dibekalkan, bahawa barang-barang itu sepatutnya-

(a) diperakukan oleh pihak berkuasa yang berwibawa;

(b) ditandakan dengan cap yang ditentukan oleh Menteri atau

(c) disertai dengan apa-apa maklumat (sama ada atau tidak terjumlah kepada atau termasuk suatu perihal dagangan) atau arahan yang berhubungan dengan barang-barang, Menteri boleh, melalui perintah, mengenakan kehendak untuk menjamin bahawa barang-barang itu diperakukan, ditandakan atau disertai sedemikian dan mengawal selia atau melarang pembekalan barang-barang dan kehendak itu boleh meliputi bentuk dan cara maklumat atau arahan itu diberikan."

(2) "Jika suatu perintah di bawah seksyen ini sedang berkuat kuasa berkenaan dengan barang-barang daripada apa-apa perihalan, mana-mana orang yang, dalam perjalanan perdagangan atau perniagaan:

(a) memperakukan;

(b) menandakan;

(c) membekalkan; atau

(d) menawarkan untuk membekalkan,

barang-barang daripada perihalan itu dengan melanggar perintah itu melakukan suatu kesalahan dan boleh, apabila disabitkan;-

jika orang itu ialah suatu pertubuhan perbadanan, didenda tidak melebihi dua ratus ribu ringgit, dan bagi kesalahan yang kedua atau yang berikutnya, didenda tidak melebihi lima ratus ribu ringgit; atau

jika orang itu bukan suatu pertubuhan perbadanan, didenda tidak melebihi satu ratus ribu ringgit atau dipenjarakan selama tempoh tidak melebihi tiga tahun atau kedua-duanya, dan bagi kesalahan 
yang kedua atau yang berikutnya, didenda tidak melebihi dua ratus lima puluh ribu ringgit atau dipenjarakan selama tempoh tidak melebihi lima tahun atau kedua-duanya."

(3) "Bagi maksud seksyen ini, "pihak berkuasa yang berwibawa" ertinya pihak berkuasa yang berwibawa yang dinamakan oleh Menteri selepas mendapat persetujuan pihak berkuasa yang berwibawa itu."

Berdasarkan kuasa yang ada di bawah Seksyen 29 Akta induk ini, suatu perintah telah dikanunkan iaitu Perintah Perihal Dagangan (Perakuan dan Penandaan Halal) 2011. Berdasarkan seksyen ini juga, Menteri Perdagangan Dalam Negeri, Koperasi dan Kepenggunaan mempunyai kuasa untuk menamakan mana-mana pihak berkuasa berwibawa bagi membuat perakuan dan pengecapan ke atas sesuatu barangan termasuk yang berkaitan dengan pensijilan halal. Melalui APD 2011 ini juga JAKIM adalah berautoriti sebagai pihak berkuasa berwibawa dalam melakukan penguatkuasaan dan pemantauan halal secara bersendirian dan tanpa perlu melibatkan pihak KPDNKK, tidak seperti sebelum ini di mana JAKIM hanya boleh menjalankan penguatkuasaan halal dengan kehadiran pihak KPDNKK sahaja. Ia telah dibuat dengan cara KPDNKK 'menurunkan' kuasa melalui kad kuasa yang dikeluarkan kepada Pegawai Hal Ehwal Islam (Pegawai JAKIM) yang dilantik sebagai Penolong Pengawal Perihal Dagangan (PPPD) bagi tujuan membantu menguatkuasakan APD 2011 apabila melibatkan penguatkuasaan halal. Pegawai JAKIM yang dilantik tersebut boleh mengambil tindakan ke atas mana-mana orang yang melakukan kesalahan berkaitan perihal halal.

Setelah pemerhatian terhadap aplikasi APD 2011 ini, serta kesalahan dan penalti yang termaktub dibawahnya, ia boleh dirumus sebagai akta induk yang dikuatkuasakan untuk memastikan perihal dagangan adalah dipatuhi sepenuhnya. Penguatkuasaan adalah tertakluk di dalam APD 2011 di mana pihak yang bertanggungjawab iaitu JAKIM dan KPDNKK sahaja yang berautoriti untuk melakukan penguatkuasaan ini.

\section{Perintah Perihal Dagangan (Perakuan dan Penandaan Halal) $2011^{29}$}

Bagi menjalankan kuasa yang diberikan di bawah Seksyen 29 APD 2011, maka Perintah Perihal Dagangan (Perakuan dan Penandaan Halal) 2011 (selepas ini dirujuk sebagai PPD (PPH) 2011) ini telah dibuat. Ia mengandungi sembilan

29 Sebagaimana Perintah Perihal Dagangan (Perakuan dan Penandaan Halal) (Pindaan) 2012 yang dikuatkuasakan bermula 1 Mac 2012. 
seksyen yang antara lain mentakrifkan siapakah pihak berkuasa berwibawa yang diberi kuasa menentusahkan status halal sesuatu makanan atau barang. Seksyen 3 menetapkan bahawa:

"Jabatan Kemajuan Islam Malaysia (JAKIM) dan Majlis Agama Islam bagi Negeri-Negeri masing-masing hendaklah menjadi pihak berkuasa berwibawa untuk memperaku bahawa mana-mana makanan, barang-barang atau perkhidmatan yang berhubung dengan makanan atau barang-barang itu adalah halal mengikut Perintah Perihal Dagangan (Takrif Halal) 2011."

Untuk merealisasikan perkara ini, maka KPDNKK selaku pengawal selia dan penguatkuasa APD 2011 telah bertindak menambah jumlah pihak berkuasa berwibawa (PBB) dan memberi kad kuasa kepada mereka. Maka dengan ini juga seramai 62 orang dengan diketuai Pengarah Bahagian Hab Halal JAKIM, semua Pegawai Hal Ehwal Islam dan semua Penolong Pegawai Hal Ehwal Islam Cawangan Pemantauan dan Penguatkuasaan, Bahagian Hab Halal, JAKIM telah dilantik sebagai Penolong Pengawal Perihal Dagangan ${ }^{30}$ di bawah Akta Perihal Dagangan 1972 pada 15 April 2010 melalui warta bertarikh 10 Jun 2010. ${ }^{31}$ Majlis Dialog antara JAKIM dan JAIN juga telah dilakukan dalam mengorak langkah terhadap pindaan ini yang mana keduadua pihak telah memberikan persetujuan terhadap pindaan akta ini.

a) Perakuan Perihal Halal

Seksyen 4(1) menjelaskan bahawa:

"semua makanan dan barang-barang tidak oleh diperihalkan sebagai halal atau diperihalkan dengan ungkapan lain untuk menunjukkan makanan atau barang-barang itu boleh dimakan atau digunakan oleh orang Islam melainkan jika: -

diperakukan sebagai halal oleh pihak berkuasa berwibawa; dan

ditandakan dengan logo sebagaimana yang dinyatakan dalam Jadual Pertama."

30 JAKIM, 'Majlis Penyerahan Kad Kuasa Pelantikan Penolong Pengawal Perihal Dagangan Kepada Pegawai Jakim di Bawah APD 1972', http://www.islam. gov.my/majlis-penyerahan-kad-kuasa-pelantikan-penolong-pengawal-perihaldagangan-kepada-pegawai-jakim-di-ba, 13 Mac 2014.

31 [P.U. (B) 265] 
Seksyen 4(2):

"Perkhidmatan yang berhubung dengan makanan atau barangbarang tidak boleh diperihalkan sebagai halal atau diperihalkan dengaan cara lain untuk menunjukkan perkhidmatan itu boleh digunakan oleh orang Islam melainkan jika ia diperakukan sebagai halal oleh pihak berkuasa berwibawa."

b) Perakuan Perihal Halal Bagi Makanan dan Barang-Barang Import

Bagi barangan import sama ada berbentuk makanan atau barang-barang lainnya, Seksyen 5(1) menegaskan:

"Semua makanan dan barang-barang import yang dipasarkan di Malaysia tidak boleh diperihalkan sebagai halal melainkan jika makanan dan barang-barang import itu mematuhi kehendak perenggan 4 atau diperakukan sebagai halal oleh badan pensijilan halal luar negara yang diiktiraf oleh JAKIM sebagaimana yang dinyatakan dalam Jadual Kedua. "32

Seksyen 5(2) pula menyatakan bahawa:

"Pengimport atau pengeluar mana-mana makanan dan barangbarang yang diperakukan sebagai halal oleh badan pensijilan halal luar negara yang diiktiraf oleh JAKIM sebagaimana yang dirujuk dalam perenggan (1) hendaklah menandakan pada makanan dan barang-barang itu, nama badan pensijilan tersebut."

Merujuk kepada perundangan di atas, seperti yang telah disebutkan terlebih dahulu, sebelum APD 2011 dikuatkuasakan, sijil halal telah dikeluarkan oleh pelbagai pihak, termasuk Jabatan Kemajuan Islam Malaysia (JAKIM), Majlis Agama Islam (MAIN) dan juga syarikat-syarikat swasta. Ini adalah kerana kelonggaran undang-undang pada masa tersebut (APD 1972) yang tidak memberikan peruntukan suatu badan yang diberikan autoriti khusus bagi mengeluarkan sijil halal apatah lagi untuk menguatkuasakannya. Disebabkan hal tersebut, maka terdapat lebih dari 10 pihak pengeluar sijil halal pada

32 Terdapat 75 badan pensijilan halal (setakat tarikh 7 Februari 2014) dari seluruh dunia yang diiktiraf oleh JAKIM sebagaimana yang tersenarai di bawah Jadual ini. Lihat dalam 'Senarai Badan Islam yang Diiktiraf,' http://www.halal.gov.my/v3/ index.php/ms/senarai-badan-islam-yang-diiktiraf, Portal Rasmi Halal Malaysia pada 31 Mac 2014. 
masa tersebut ${ }^{33}$ yang terdiri dari pelbagai jenis sijil dikeluarkan oleh pihakpihak swasta yang kebanyakannya mengenakan yuran yang tinggi dan meletakkan keuntungan di hadapan serta ada juga yang boleh dipertikaikan kebolehpercayaannya. Selain itu, timbul juga kekhuatiran tentang isu keselamatan produk serta kualiti produk yang mungkin diabaikan sungguhpun sijil halal dikeluarkan. Malah tidak mustahil juga berlaku sijil halal dikeluarkan kerana hubungan baik pemohon dengan pihak swasta yang mengeluarkan sijil halal tersebut.

Sehubungan dengan itu, pihak JAKIM telah menyelaraskan logo halal yang dikeluarkan oleh pihak mereka termasuk pihak MAIN/JAIN. Rajah 1 di bawah adalah logo halal JAKIM yang telah didaftarkan di bawah Akta Cap Dagangan 1976. Mana-mana syarikat yang diluluskan permohonan sijil halal hanya boleh mempamerkan logo tersebut, manakala logo-logo yang terpapar dalam Rajah 2 adalah dilarang.

Rajah 1: Logo halal JAKIM yang terkini.

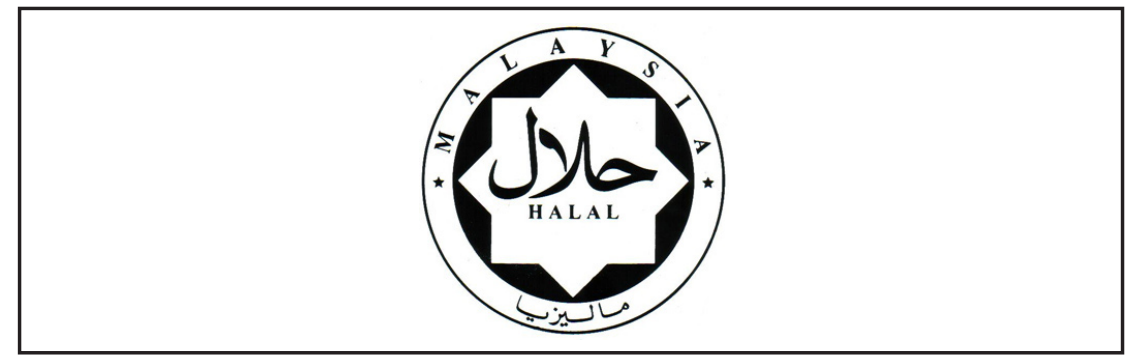

Sumber: JAKIM.

Rajah 2: Logo-logo halal yang dilarang penggunaannya selepas APD 2011.

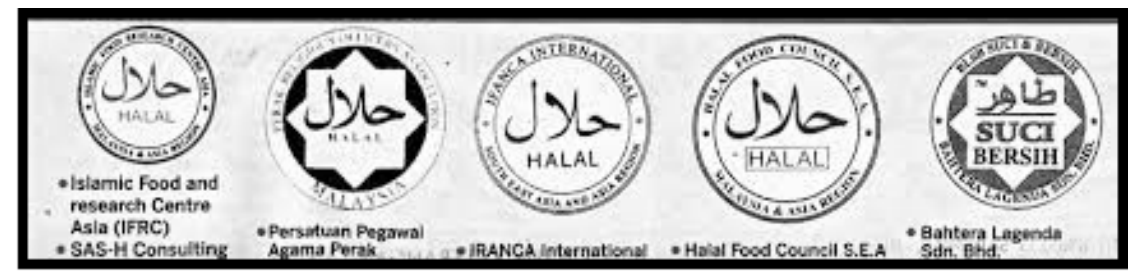

Sumber: JAKIM.

33 Ahmad Hidayat Buang \& Zalina Zakaria, 'Halal Food Industries in Malaysia: Some Assessment on the Adequacy of Regulatory and Supervisory Framework,' (Kertas kerja International Seminar on Halal Food and Products: Challenges and Prospects in Global Market, oleh Islamic University College of Malaysia, Hotel Marriot, Putrajaya, pada 28-30 September 2004). 
Jadual 2 berikut merumuskan perbandingan antara APD 1972 dengan APD 2011.

Jadual 2: Perbandingan antara APD 1972 dengan APD 2011.

\begin{tabular}{cll}
\hline Bil. & \multicolumn{1}{c}{ APD 1972 } & \multicolumn{1}{c}{ APD 2011 } \\
\hline 1. & Tiadaperuntukanundang-undang & Seksyen 29 memperuntukkan \\
memberikan bidangkuasa khusus & satu bidang kuasa khusus kepada \\
kepada badan bersijilan halal & badan pensijilan halaldi Malaysia \\
untuk mengeluarkan sijil halal & iaitu JAKIM (JAIN) sebagai \\
& satu-satunya badan pengeluar \\
& sijil halal Malaysia
\end{tabular}

2. Disebabkan hal tersebut, Peruntukan Seksyen 29 juga mana-mana pihak badan boleh memberi impak bahawa mengeluarkan sijilhalalwalaupun tiada badan lain yang boleh pihak tersebut adalah pihak mengeluarkan sijil halal selain swasta JAKIM

3. JAKIM sungguhpun dikenali sebagai badan pentadbir halal pada masa tersebut, namun ia tidak boleh menjalankan penguatkuasaan halal, kerana penguatkuasa dan pentadbir akta adalah pihak Kementerian Perdagangan dalam Negeri dan Hal Ehwal Pengguna (dahulunya dikenali sebagai KPDNHEP). JAKIM hanya boleh memantau dengan adanya kehadiran pihak KPDNKK sahaja.

4. Tiada peruntukan tentang 'selfdeclaration' halal. Contohnya, banyak pihak menggunakan perkataan 'makanan orang Islam', 'ditanggung halal', 'buffet Ramadhan', dan pelbagai cara lain untuk menunjukkan halal

Melalui peruntukan Seksyen 28 Akta 2011, yang apabila JAKIM dilantik sebagai pihak berkuasa berwibawa melalui kad kuasa yang dikeluarkan kepada pegawai JAKIM oleh pihak KPDNKK, pegawai JAKIM boleh membuat pemantauan halal tanpa kehadiran pihak KPDNKK. 


\begin{tabular}{cll}
\hline Bil. & \multicolumn{1}{c}{ APD 1972 } & \multicolumn{1}{c}{ APD 2011 } \\
\hline 5. & Penalti adalah tidak tinggi, dan & Penalti adalah jauh lebih tinggi \\
kebanyakan kes pelangganan & (sila rujuk Jadual 2) boleh \\
hanyalah dikenakan kompaun & menjadi 'deterrent'. Juga \\
& $\begin{array}{l}\text { sahaja yang mungkin tidak } \\
\text { menjadi 'deterrent' kepada } \\
\text { pesalah. }\end{array}$ & mahkamah. \\
& &
\end{tabular}

Sumber: Analisis Penyelidik.

Jadual 3 di bawah pula menjelaskan tentang perbandingan antara penalti kesalahan di bawah Seksyen 10 dan Seksyen 11 APD 1972 dengan penalti di bawah APD 2011 di bawah Seksyen 28 dan 29.

Jadual 3: Perbandingan antara Penalti Kesalahan di bawah Seksyen 10 dan Seksyen 11 Akta Perihal Dagangan 1972 (APD1972) dengan Seksyen 28 \& Seksyen 29 Akta Perihal Dagangan 2011 (APD2011).

\begin{tabular}{|c|c|c|}
\hline $\begin{array}{l}\text { Penalti kesalahan } \\
\text { APD } 1972 \text { (Seksyen } \\
10 \text { dan Seksyen 11) }\end{array}$ & $\begin{array}{c}\text { Penalti di bawah } \\
\text { APD } 2011 \\
\text { (Seksyen 28) }\end{array}$ & $\begin{array}{c}\text { Penalti di bawah } \\
\text { APD 2011 } \\
\text { (Seksyen 29) }\end{array}$ \\
\hline $\begin{array}{l}\text { Individu } \\
\text { 1.Kesalahan pertama:- } \\
\text { Denda sehingga } \\
\text { RM100,000 atau } 3 \\
\text { tahun penjara atau } \\
\text { kedua-duanya } \\
\text { 2.Kesalahan kedua } \\
\text { dan berikutnya:- } \\
\text { Denda sehingga } \\
\text { RM200,000 atau } \\
\text { 6tahun penjara atau } \\
\text { kedua-duanya }\end{array}$ & $\begin{array}{l}\text { Individu } \\
\text { 1.Kesalahan pertama:- } \\
\text { Denda sehingga RM } 1 \\
\text { juta atau } 3 \text { tahun penjara } \\
\text { atau kedua-duanya } \\
\text { sekali. } \\
\text { 2. Kesalahan kedua dan } \\
\text { berikutnya:- } \\
\text { Denda tidak melebihi } \\
\text { RM5 juta atau } 5 \text { tahun } \\
\text { penjara atau kedua- } \\
\text { duanya sekali. }\end{array}$ & $\begin{array}{l}\text { Individu } \\
\text { Kesalahan pertama:- } \\
\text { Denda tidak melebihi } \\
\text { RM100,000 atau } 3 \\
\text { tahun penjara atau } \\
\text { kedua-duanya sekali } \\
\text { Kesalahan kedua:- } \\
\text { Denda RM250,000 }\end{array}$ \\
\hline
\end{tabular}




\begin{tabular}{lll}
\hline $\begin{array}{c}\text { Penalti kesalahan } \\
\text { APD 1972 (Seksyen } \\
\text { 10 dan Seksyen 11) }\end{array}$ & \multicolumn{1}{c}{$\begin{array}{c}\text { Penalti di bawah } \\
\text { APD 2011 } \\
\text { (Seksyen 28) }\end{array}$} & $\begin{array}{c}\text { Penalti di bawah } \\
\text { APD 2011 } \\
\text { (Seksyen 29) }\end{array}$ \\
\hline $\begin{array}{l}\text { Pertubuhan/ } \\
\text { Perbadanan }\end{array}$ & $\begin{array}{l}\text { Pertubuhan/ } \\
\text { Perbadanan }\end{array}$ & $\begin{array}{l}\text { Pertubuhan/ } \\
\text { Perbadanan }\end{array}$ \\
1.Kesalahan pertama:- & 1.Kesalahan pertama:- & Kesalahan pertama:- \\
Denda dikenakan & Denda adalah sehingga & Denda adalah sehingga \\
sehingga RM250,000 & RM5 juta & RM250,000 \\
& 2. Kesalahan kedua dan & Kesalahan kedua:- \\
& berikutnya:- & Denda RM500,000. \\
& Denda tidak melebihi & \\
& RM10juta & \\
\hline
\end{tabular}

Sumber: Analisis Penyelidik.

Berdasarkan kepada penerangan yang telah dinyatakan di dalam Jadual 3, dilihat bahawa penalti yang dikenakan bagi pesalah-pesalah dalam APD 2011 boleh memberi tekanan dan pengajaran kepada mereka supaya tidak mengulangi kesalahan tersebut disebabkan kadar penalti yang begitu tinggi terhadap pesalah sama ada bagi individu atau pertubuhan. Secara logik, jumlah tersebut merupakan nilai penalti yang berada di luar kemampuan mereka. Sebagai contoh, mengikut statistik berkaitan penyalahgunaan logo halal yang didakwa di bawah APD2011 oleh pihak penguatkuasaan KPDNKK ${ }^{34}$ dari tahun 2011 hingga 2013 (Julai 2013), sejumlah 132 kes telah diambil tindakan dengan nilai rampasan berjumlah RM374,636. Manakala dari aspek pelaksanaan penalti pula, dari tahun 2007 hingga 2013 (Julai 2013) sejumlah 72 kes telah dikompaun dan didakwa di Mahkamah, dengan nilai kompaun atau denda berjumlah RM30,550. ${ }^{35}$

Manakala bagi JAKIM selaku satu-satunya pihak berkuasa yang telah dilantik untuk 'mentadbir' halal di negara ini. Bagi tujuan pelaksanaan APD 2011, JAKIM telah mengeluarkan dua pekeliling iaitu;

34 Haji Rabani Soyan (Ketua Penolong Pengarah Kanan Unit Perihal Dagangan, Bahagian Penguatkuasaan KPDNKK) dan Hamzah Mahadi (Ketua Penolong Pengarah Unit Perihal Dagangan, Bahagian Penguatkuasaan KPDNKK), dalam temu bual bersama beliau, pada 2 Oktober 2013.

35 Haji Rabani Soyan (Ketua Penolong Pengarah Kanan Unit Perihal Dagangan, Bahagian Penguatkuasaan KPDNKK) dan Hamzah Mahadi (Ketua Penolong Pengarah Unit Perihal Dagangan, Bahagian Penguatkuasaan KPDNKK), dalam temu bual bersama beliau, pada 2 Oktober 2013. 
1. Pekeliling Pensijilan Halal Malaysia Bil. 1/2011

2. Pekeliling Pensijilan Halal Malaysia Bil. 3/2012

Pekeliling Pensijilan Halal Malaysia Bil. 1/2011 telah dikeluarkan bertujuan untuk memaklumkan berkenaan pemansuhan Akta Perihal Dagangan 1972 (Akta 87) kepada penggantian akta baru iaitu Akta Perihal Dagangan 2011 (Akta 730) dan Perintah-Perintah Perihal Dagangan Berkaitan Halal yang telah diluluskan di Parlimen pada 11 Julai 2011. Objektif utama pekeliling ini adalah untuk memaklumkan kesemua pengusaha produk dan perkhidmatan bahawa bermula 1 Januari 2012, sijil dan logo halal yang dikeluarkan atau dipohon sama ada secara 'self declaration' atau yang dikeluarkan oleh manamana syarikat swasta tidak lagi dibenarkan. 'Self declaration' bermaksud perakuan persendirian tentang sesuatu bahan ramuan tidaklah boleh diterima dalam pensijilan halal di Malaysia. Berdasarkan Seksyen 72, tindakan tersebut adalah merupakan suatu kesalahan yang boleh dihukum di bawah Seksyen 29 APD 2011 di bawah Perintah Perihal Dagangan (Perakuan dan Penandaan Halal) 2011. Pada Seksyen 8 akta tersebut, kesalahan boleh dikenakan kepada mana-mana orang yang memperakukan mana-mana makanan atau barangan itu halal. Manakala menurut Seksyen 73, hanya JAKIM dan MAIN sahaja yang boleh mengeluarkan sijil halal Malaysia di mana sijil ini terpakai untuk semua produk dan perkhidmatan yang dikeluarkan di Malaysia.

\section{KESIMPULAN}

Secara asasnya, tujuan penggubalan APD 2011 ini adalah untuk menggalakkan amalan perdagangan yang baik dengan melarang perihal dagangan palsu dan pernyataan, pengendalian dan amalan palsu. Penggubalan APD 2011 bukan sekadar tentang perundangan halal, tetapi turut melibatkan penambahbaikan perundangan berkaitan harta intelek, halal, iklan penalti kesalahan dan aspek penguatkuasaan berbanding APD 1972 terdahulu. ${ }^{36}$

Penggubalan ini juga merupakan satu keperluan. Pemakaian APD 1972 yang lalu memperlihatkan kecelaruan yang jelas dalam perundangan halal di Malaysia terutama dalam isu berkaitan penguatkuasaan. Walaupun JAKIM merupakan badan yang berautoriti untuk permohonan dan pensijilan halal, namun pihak KPDNKK masih kekal sebagai pihak yang berkompeten dalam penguatkuasaan dan segala tindakan penguatkuasaan dan penyitaan hanya tertakluk kepada pihak ini sahaja.

36 Haji Rabani Soyan (Ketua Penolong Pengarah Kanan Unit Perihal Dagangan, Bahagian Penguatkuasaan KPDNKK) dan Hamzah Mahadi (Ketua Penolong Pengarah Unit Perihal Dagangan, Bahagian Penguatkuasaan KPDNKK), dalam temu bual bersama beliau, pada 2 Oktober 2013. 
Di samping itu, kadar penalti yang boleh dikenakan terhadap pesalah melalui APD 2011 merupakan suatu nilai yang amat berpatutan jika dibandingkan dengan kesalahan pihak pengeluar yang menyalahgunakan logo halal kepada pengguna, sehinggakan pengguna terpedaya dalam membuat pilihan. Situasi ini jelas menggambarkan kepada pihak pengguna bahawa

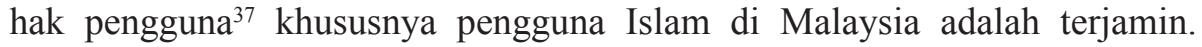
Penyeragaman logo halal ini juga dilihat mampu memudahkan pemantauan dan penguatkuasaan halal berbanding APD 1972 yang masih membenarkan pihak lain untuk membuat pensijilan halal. ${ }^{38}$ Perlu dinyatakan bahawa permohonan sijil halal adalah bersifat sukarela dan APD 1972 tidak melarang mana-mana badan untuk menawarkan perkhidmatan pensijilan halal kepada umum. ${ }^{39}$ Namun, melalui peruntukan dalam APD 2011, JAKIM dan MAIN telah dijadikan sebagai agensi berwibawa yang mengeluarkan sijil dan logo halal Malaysia. Perkembangan ini dilihat mampu memartabatkan agensi Islam di bawah kerajaan dan memantapkan lagi fungsi mereka.

\section{PENGHARGAAN}

Penulis ingin merakamkan setinggi-tinggi penghargaan kepada Universiti Malaya kerana membiayai penyelidikan projek RP012B-13HNE, serta ucapan terima kasih kepada Fahmi Khawarizmi Mahmud, Pembantu Penyelidik Projek, di atas bantuan penyelidikan yang diberikan.

37 Hak-hak pengguna ialah hak mendapatkan keperluan asas, hak mendapatkan barangan dan produk yang selamat, hak untuk mendapatkan maklumat, hak untuk membuat pilihan, hak untuk menyuarakan pendapat, hak untuk mendapatkan ganti rugi, hak untuk mendapatkan pendidikan pengguna, hak untuk hidup dalam alam sekitar yang sihat dan selamat. Mohd Hamdan Adnan, Perjuangan Perundangan Pengguna (Selangor: IBS Buku Sdn. Bhd., 2005), 75-116.

38 Badan yang dibolehkan sebelum ini adalah seperti Bahtera Lagenda Sdn. Bhd, Islamic Food and Research Council (IFRC), Perak Religious Officer Association, Halal Food Council S.E.A, SAS-H Consultancy, IFANCA International. Kini penggubalan APD 2011 ini telah memansuhkan pihak-pihak ini dalam memberi pengesahan halal.

39 Ahmad Hidayat Buang \& Zulzaidi Mahmod, 'Isu dan Cabaran Badan Pensijilan Halal di Malaysia,' Jurnal Syariah 20/3 (2012): 275. 


\section{RUJUKAN}

Ahmad Hidayat Buang \& Zalina Zakaria, 'Halal Food Industries in Malaysia: Some Assessment on the Adequacy of Regulatory and Supervisory Framework,' (Kertas kerja International Seminar on Halal Food and Products: Challenges and Prospects in Global Market, oleh Islamic University College of Malaysia, Hotel Marriot, Putrajaya, pada 28-30 September 2004).

Ahmad Hidayat Buang \& Zulzaidi Mahmod, 'Isu dan Cabaran Badan Pensijilan Halal di Malaysia,' Jurnal Syariah, 20/3 (2012): 271-288.

Bernama, 'Only Halal Logo Issued by Jakim Will be Accepted from Next Year', http://www.hdcglobal.com/upload-web/cms-editor-files/HDC122/file/28Sep2011\%28Bernama_com\%29-OnlyHalalLogoIssuedbyJa kimWillbeAcceptedfromNextYear.jpg, 27 Mac 2014.

JAKIM, 'Badan Pensijilan Halal dari Seluruh Dunia yang Diiktiraf JAKIM,' http://www.halal.gov.my/v3/index.php/ms/senarai-badan-islam-yangdiiktiraf, 31 Mac 2014.

JAKIM, 'Halal di bawah Akta Perihal Dagangan 2011,' dicapai dalam laman sesawang Jabatan Kemajuan Islam Malaysia, http://www.islam.gov.my/ en/keratan-akhbar/halal-di-bawah-akta-perihal-dagangan-2011, pada 29 Mac 2014.

JAKIM, 'Majlis Penyerahan Kad Kuasa Pelantikan Penolong Pengawal Perihal Dagangan Kepada Pegawai Jakim di Bawah APD 1972', http://www.islam.gov.my/majlis-penyerahan-kad-kuasa-pelantikanpenolong-pengawal-perihal-dagangan-kepada-pegawai-jakim-di-ba, 13 Mac 2014.

Lokman Abd Rahman, Produk Halal: Kepenggunaan, Teknologi dan Prosedur (Melaka: Jabatan Agama Islam Melaka dan Majlis Agama Islam Melaka, 2002).

Mohd Hamdan Adnan, Perjuangan Perundangan Pengguna (Selangor: IBS Buku Sdn. Bhd., 2005).

T.P., 'Destinasi Produk Halal Dunia,' Utusan Malaysia, 6 Mei 2008.

T.P., 'Jalan Mudah,' Harian Metro, 5 Januari 2011.

T.P., 'New Rules on Halal Cert.,'News Strait Times, 29 September 2011.

T.P., 'Sijil Halal Tidak Sah: Peniaga Masih Berdegil,' Harian Metro, 10 April 2011.

Zalina Zakaria, 'Keberkesanan Undang-Undang Makanan dan Produk Halal di Malaysia,' Jurnal Syariah, 12/2 (2004): 95-106. 


\section{Statut}

Akta Perihal Dagangan 1972.

Akta Perihal Dagangan 2011.

Pekeliling Pensijilan Halal Malaysia Bil. 1/2011.

Perintah Perihal Dagangan (Penandaan Makanan) 1975.

\section{Temu bual}

Fakheezah Borhan (Penolong Pengarah Bahagian Standardisasi, Jabatan Standard Malaysia), dalam temu bual bersama beliau, pada 7 Oktober 2013.

Hajah Hakimah Mohd Yusoff (Pengarah Bahagian Hab Halal JAKIM), dalam temu bual bersama beliau, pada 6 September 2013.

Hamzah Mahadi (Ketua Penolong Pengarah Unit Perihal Dagangan, Bahagian Penguatkuasaan KPDNKK), dalam temu bual bersama beliau, pada 2 Oktober 2013.

Nik Nazira Nik Yahya (Penolong Pengarah Kanan, Bahagian Pengurusan Strategik), dalam temu bual bersama beliau, pada 7 Oktober 2013.

Rabani Soyan (Ketua Penolong Pengarah Kanan Unit Perihal Dagangan Bahagian Penguatkuasaan KPDNKK), dalam temu bual bersama beliau, pada 2 Oktober 2013. 